Research article

\title{
DETECTION OF ANTIBODIES AGAINST LUMPY SKIN DISEASE VIRUS BY VIRUS NEUTRALIZATION TEST AND ELISA METHODS
}

\author{
SAMOJLOVIĆ Milena ${ }^{1}$, POLAČEK Vladimir ${ }^{1}$, GURJANOV Vladimir ${ }^{2}$, \\ LUPULOVIĆ Diana ${ }^{1}$, LAZIĆ Gospava ${ }^{1}$, PETROVIĆ Tamaš ${ }^{1}$ LAZIĆ Sava ${ }^{1 *}$
}

${ }^{1}$ Scientific Veterinary Institute „Novi Sad“, Novi Sad, Republic of Serbia;

${ }^{2}$ Veterina DOO, PIK Bečej, Bečej, Republic of Serbia

(Received 13 July 2018, Accepted 21 February 2019)

Infection of cattle with lumpy skin disease virus (LSDV) is very important from the aspect of livestock production. Although it can cause significant economic losses, available serological assays are still not sufficiently efficient and reliable. A 3-day VNT was performed using Madin-Darby bovine kidney (MDBK) cell line and LSDV isolated from clinically infected cow to improve serological diagnostics of lumpy skin disease (LSD).

In total, 325 cattle sera samples were tested in order to compare the performances of VNT and ELISA. Tested samples originated from 125 cows before the occurrence of LSD in the Republic of Serbia and 200 tested samples originated from vaccinated cows. Sera samples from vaccinated cows were collected starting from the vaccination day to 4 months after vaccination. In 7 different time intervals after vaccination sampling was carried out in 20 cows originating from one herd and in 3 different time intervals in 20 cows originating from a different herd each time of sampling.

Out of 200 samples from vaccinated cows, antibodies against LSDV were detected in $68(34 \%)$ samples by VNT, and in $60(30 \%)$ samples by ELISA. No positive finding was detected by VNT in samples collected before the occurrence of LSD in Serbia, while one positive finding was detected in the same samples by ELISA. The first presence of antibodies in vaccinated cattle was detected by both tests 20 days after vaccination, and the largest number of animals with antibodies against LSDV was detected 30 days after vaccination.

Comparing the results obtained by VNT and ELISA, it was calculated that kappa index was 0.913 . The specificity of VNT and ELISA was $100 \%$ and $99.2 \%$, respectively. VNT is simpler to perform compared to the recommended virus neutralization test by the OIE and can improve LSD serological diagnostics with additional sensitivity testing.

Key words: antibodies, ELISA, Lumpy skin disease virus, Virus neutralization test, specificity, sensitivity

\footnotetext{
*Corresponding author: e-mail: lazic@niv.ns.ac.rs
} 


\section{INTRODUCTION}

Lumpy Skin Disease (LSD) is a contagious disease of cattle and buffaloes, although the disease was found in some wildlife species (impalas and gazelles). The disease is characterized by changes on the skin and mucous membranes in the form of inflammatory necrotic spots, which can cause severe general health disorders, significant decrease in milk production and growth, abortions and sterility [1]. Significant changes in hematological and biochemical parameters were observed in infected animals [2]. LSD is on the OIE list of notifiable diseases, because of its great economic impact and huge economic losses it can cause [3]. However, Carn and Kitching [4] found that not all experimentally infected cattle would display clinical signs of the disease, so this must be taken into consideration when determining measures for preventing the spread of the disease.

The causative agent of LSD is a virus belonging to the family Poxviridae, subfamily Capripoxviridae, genus Capripox [5]. Beside lumpy skin disease virus (LSDV), genus Capripox consists of sheeppox virus (SPV) and goatpox virus (GPV). Viruses within this genus share $97 \%$ of nucleotide identity are serologically indistinguishable and cross-protective, so they are used in vaccines for the prevention of these diseases [6-8].

The first case of LSD in cattle in the Republic of Serbia was reported on June 5, 2016. A total of 225 cases of the disease and 267 infected cattle were registered. The last case of the disease in the Republic of Serbia was registered on October 1, 2016. [9]. The virus was detected in the samples from skin nodules, and afterwards isolated [10]. The isolated LSDV named SERBIA/Bujanovac/2016 was sequenced in the length of the complete genome and submitted into NCBI GenBank under the number KY702007. Sequencing of the genome revealed that LSDV isolated in Serbia consists of 150661 nucleotides and that it shares $99.95 \%$ of nucleotide identity with the Neethling Warmbaths LW strain, which was isolated in South Africa in 1999 [11].

According to the recommendation of the World Organization for Animal Health (OIE) detection of antibodies against LSDV can be performed by virus neutralization test, agar gel immunodiffusion test, indirect fluorescence test, ELISA as well as by Western blot [12]. Virus neutralization test is "the gold standard" and is considered the most specific method for the detection of antibodies against LSDV, but it is not sensitive enough to identify each animal that was in contact with the virus [13]. Immunodiffusion and immunofluorescence tests for the detection of antibodies against LSDV, are less specific, while Western blot is specific and sensitive enough, but complicated to set up and very expensive for routine use, while ELISA requires standardization of the coated antigen in the microtiter plates [12,14]. On the other hand, main advantages of ELISA are its cost, speed and possibility to run a large number of samples on one plate [15]. Based on the current knowledge on the detection of antibodies against LSDV, OIE indicates that virus neutralization test is suitable for determining status of the herd and individual animals to LSDV infection. Also, according to the obtained results of current studies, virus neutralization test can be 
used for the confirmation of the clinical status of infected animals, determining the eradication policy and prevalence of LSD, or immune status of vaccinated cattle in the heard. However, it was determined that cattle with mild or asymptomatic infection will not always develop antibody levels detectable with VNT, as well as that vaccinated cattle will sometimes develop low levels of antibodies below the detection limit [9].

As recommended by OIE, key elements of VNT Protocol include using Capripoxvirus of standard titer of $100 \mathrm{TCID} / 50,1: 5$ to 1:500 dilution of test sera, Vero or LT (lamb testis) cells, or other cells susceptible to Capripoxvirus on which the virus was titrated. Testing is done in flat-bottomed 96-well microtiter plates for cell culture. Microtiter plates are incubated for 9 days at $37^{\circ} \mathrm{C}$. Samples are considered positive if neutralization index is $\geq 1: 5[12]$.

Effectors of cell mediated immunity play a dominant role in the development of protection against LSD, however antibodies, as effectors of the humoral immunity, are important indicators of immune reactivity in both vaccinated and infected animals $[3,14,16,17]$. Antibodies against LSDV in vaccinated animals appear 10 days after vaccination and remain detectable in the majority of vaccinated animals 30 days after vaccination [18].

VNT and ELISA have been used for the detection of antibodies against LSDV in different studies. Hedger and Hamblin [19] found antibodies in wild animals by VNT. Babiuk et al. [20,21] detected antibodies in experimentally infected animals with LSDV by comparative testing of samples by VNT and ELISA. Similarly, Bowden et al. [14] performed comparative testing of samples by VNT and ELISA to detect antibodies against LSDV in experimentally infected animals. Walid et al. [22] detected antibodies against LSDV in clinically infected cows, fevered cows, and in-contact cows. Furthermore, Tilahun et al. [23] used VNT to follow seroconversion in cows vaccinated against LSD.

The aim of this paper was to present the results of detection of antibodies against LSDV obtained by comparative testing of cattle sera samples by virus neutralization test (VNT) and ELISA, in parallel. In addition to that, the aim of this paper was to present the compatibility of the obtained results, as well as the results of specificity and sensitivity of VNT and commercial ELISA (ELISA) for the detection of antibodies against LSDV.

\section{MATERIAL AND METHODS}

Sera samples of cows from Južnobački and Srem Districts were used in this study (Figure 1). In this area LSD was not reported during the LSD outbreak in Serbia in 2016 and vaccination against LSD started during July 2016. Tested cows were of different breed (Black and Red Holstein, Simmental breed, and crosses of these breeds) and age (2-6 years). 


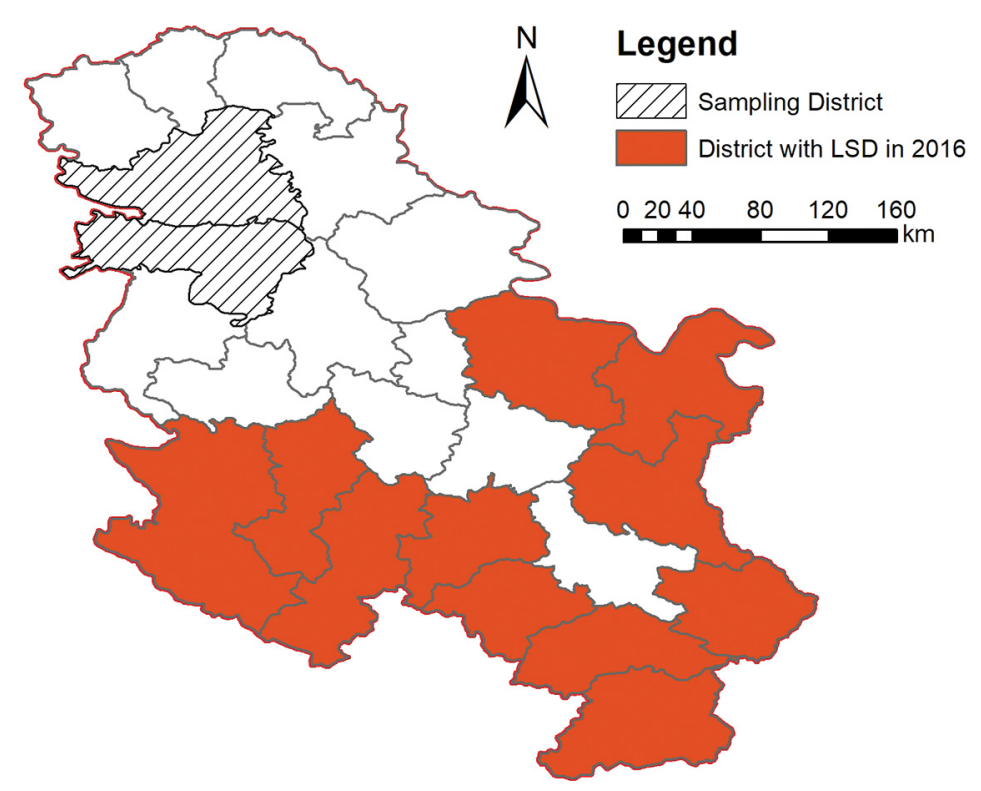

Figure 1. Republic of Serbia - Districts with LSD in 2016 and Sampling Districts

\section{Blood sera samples from the sera bank of Scientific Veterinary Institute "Novi Sad"}

From the sera bank of the Scientific Veterinary Institute "Novi Sad" 125 cattle sera samples were randomly chosen. These samples were collected during 2015 and until June 1, 2016, i.e. before LSD outbreak in Serbia. From the year 2015, 94 samples were tested, and from the year 2016, 31 samples were tested. Tested cattle originated from 52 different farms.

\section{Blood sera samples from vaccinated cows}

Vaccination of cattle against LSD in the Republic of Serbia was conducted with „OBP Lumpy Skin Disease“ vaccine (Onderstepoort, Biological Products). Samples were collected from randomly selected vaccinated cows originating from four herds. In the 20 cows originating from one herd, sampling was carried out in 7 different time intervals after vaccination. A total of 140 sera samples from the same 20 cows of one herd were collected on days $0,10,20,30,45,60$, and 75 after vaccination. Sampling was also carried out in 3 different time intervals after vaccination in 20 cows originating from a different herd each time of sampling. In this way, 60 more samples were collected on days 90, 105 and 120 after vaccination. Hence, testing was performed in a total of 200 sera samples collected from vaccinated cows. 


\section{Commercial ELISA set kit}

A commercial ELISA kit „ID Screen ${ }^{\circledR}$ Capripox Double Antigen Multi-species“, manufactured by „IDvet, (France), Lot: B54, was used to detect specific antibodies against LDSV. Testing was carried out according to manufacturer's instruction.

The results of the test are defined based on the calculated S/P ratio (Formula 1). If the $\mathrm{S} / \mathrm{P}$ ratio is higher than $30 \%$, tested sample is defined as positive on the presence of antibodies against LSDV.

$$
\mathrm{S} / \mathrm{P}=\frac{\text { test sample OD }- \text { negative control OD }}{\text { positive control OD }- \text { negative control OD }} \times 100
$$

Formula 1. Calculation of S/P ratio

\section{Virus neutralization test}

Virus neutralization test was performed using LSD virus isolate (SERBIA/Bujanovac/ 2016). The LSDV was isolated from skin nodules of a clinically infected cow during LSD outbreak in Serbia. The virus isolate was cultivated and titrated on MDBK cell line (ATCC, CCL-22). The titer of virus isolate used in VNT was $6,0 \log _{10}$ TCID/50 after the fourth passage.

VNT was performed in commercial flat-bottomed 96-well microtiter plates for cell culture manufactured by „Sarstedt“, (Lot: 2079082) using cell culture medium Eagle MEM with Hepes buffer, manufactured by „Sigma“ (Lot: SLBQ2618V), with 10\% fetal bovine serum, manufactured by Capricorn (Lot: CP16-1377).

\section{Virus neutralization test procedure}

VNT procedure:

- $50 \mu \mathrm{L}$ of cell culture medium with $10 \%$ fetal bovine serum was added to all wells of the microtiter plate, except virus control, cell control and virus back titration wells. Control sera and test sera were then titrated in a volume of $50 \mu \mathrm{L}$ using twofold dilutions from 1:2 to 1:256

- $50 \mu \mathrm{L}$ of appropriate dilution of stock virus was added to every well containing control and test sera

- Microtiter plates were incubated for one hour at $37^{\circ} \mathrm{C}$ and after incubation $100 \mu \mathrm{L}$ of $\mathrm{MDBK}$ cell suspension of concentration $185000 \mathrm{cell} / \mathrm{ml}$ was added to every well containing control and test sera

- Microtiter plates were incubated for three days ( 72 hours) in an incubator at $37^{\circ} \mathrm{C}$, after that, plates were read microscopically for the presence of cytopathogenic effect (CPE) of LSD virus

VNT contained the following controls:

- Positive serum control (antibody titer value 1:8 - 1:32) 
- Negative serum control (fetal bovine serum)

- Controll of MDBK cells in 8 wells (Figure 2A)

- Control of working dilution of stock virus of 100 TCID/50 in 8 wells (Figure 2B)

- A back titration of the working dilution of stock virus using eight wells per tenfold dilution $(10,1$ and 0 TCID/50 in $50 \mu \mathrm{L}$ ) (Figures $2 \mathrm{C}$ and $2 \mathrm{D}$ showing cytopathogenic effect of 10 and 1 TCID/50 of diluted virus).

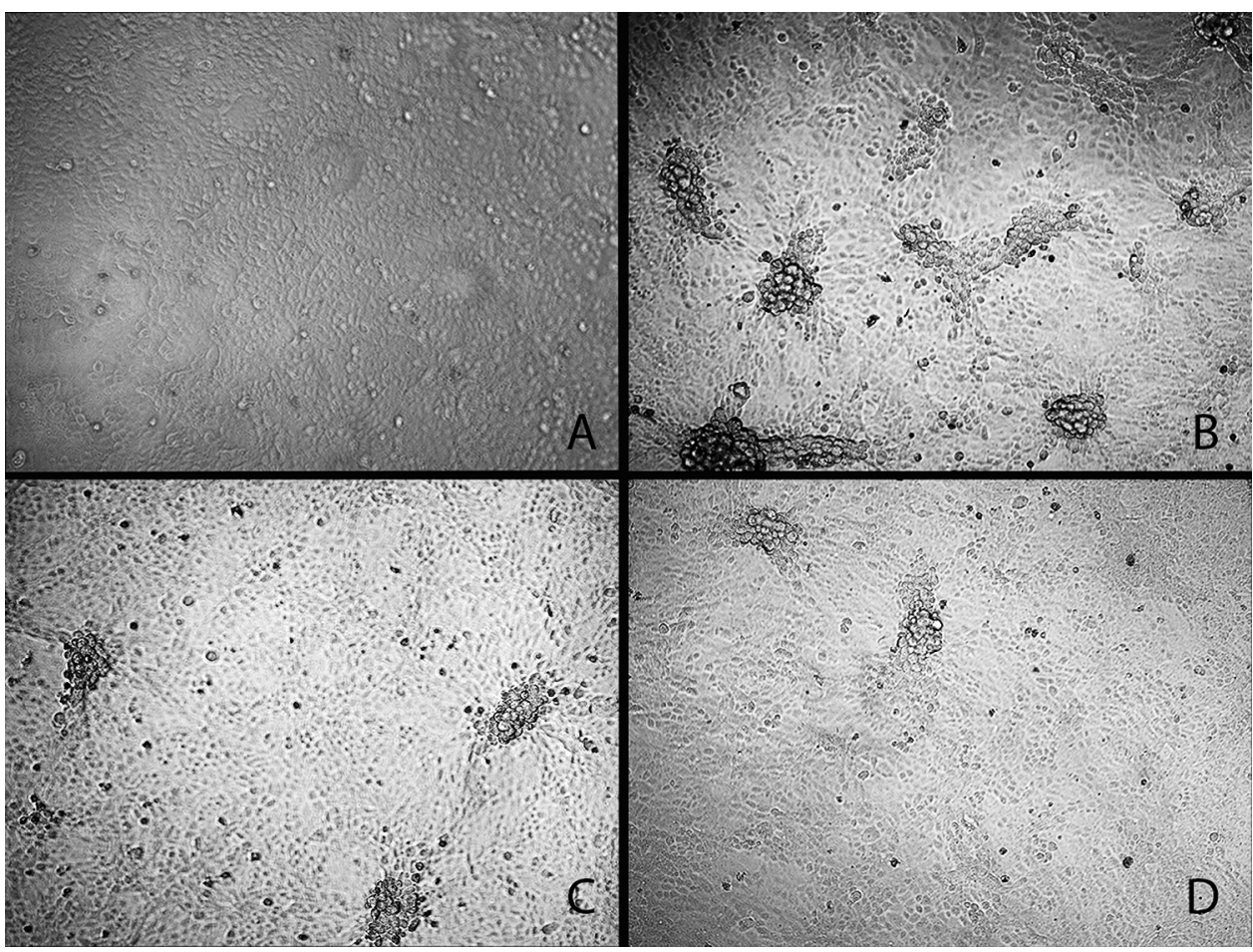

Figure 2. The control of MDBK cell line (A), the controls of LSDV of 100 TCID/50 (B), LSDV of 10 TCID/50 (C) and LSDV of 1 TCID/50 (D)

Reading of the results with verification - criteria

- Virus titer in back titration (3 serial tenfold dilutions of working virus) was within 30 and 300 TCID/50

- No cytomorphological changes were observed in cell line control wells

- Antibody titer of positive control serum was 1:8 - 1:32,

- Antibody titer of negative control serum was $<1: 2$

- Antibody titer of test serum was the last dilution of serum in which no CPE of LSD virus was observed 
- Determined antibody titer of 1:2 or higher was considered to be a positive finding for the presence of antibodies against LSDV.

\section{Statistical analysis}

For the statistical analysis of obtained results in this study kappa test was used according to: http://epitools.ausvet.com.au/content.php?page=Compare2Tests, and specificity and sensitivity of the compared methods were calculated according to Thrusfield [24].

\section{RESULTS}

\section{Results of detection of antibodies against LSDV by VNT and ELISA}

The results of antibody detection against LSDV in 125 samples from the sera bank of the Scientific Veterinary Institute "Novi Sad" and 200 samples from vaccinated cattle, obtained by both VNT and ELISA, are presented in Table 1.

Table 1. Results of antibody detection against LSDV by VNT and ELISA

\begin{tabular}{|c|c|c|c|c|c|c|c|}
\hline \multirow[b]{2}{*}{$\begin{array}{l}\text { Tested } \\
\text { samples }\end{array}$} & \multirow[b]{2}{*}{$\begin{array}{l}\text { Number } \\
\text { of tested } \\
\text { samples }\end{array}$} & \multicolumn{3}{|c|}{ Results of VNT } & \multicolumn{3}{|c|}{ Results of ELISA } \\
\hline & & $\begin{array}{l}\text { Number } \\
\text { of positive } \\
\text { samples }\end{array}$ & $\begin{array}{l}\text { Number } \\
\text { of negative } \\
\text { samples }\end{array}$ & $\begin{array}{c}\text { Positive } \\
\text { samples } \\
(\%)\end{array}$ & $\begin{array}{l}\text { Number } \\
\text { of positive } \\
\text { samples }\end{array}$ & $\begin{array}{l}\text { Number } \\
\text { of negative } \\
\text { samples }\end{array}$ & $\begin{array}{c}\text { Positive } \\
\text { samples } \\
(\%)\end{array}$ \\
\hline $\begin{array}{l}\text { Samples from the } \\
\text { sera bank }\end{array}$ & 125 & 0 & 125 & 0 & $1 *$ & 124 & 0.8 \\
\hline $\begin{array}{l}\text { Samples collected } \\
\text { from vaccinated } \\
\text { cattle }\end{array}$ & 200 & 68 & 132 & 34 & 60 & 140 & 30 \\
\hline TOTAL & 325 & 68 & 257 & 20.92 & 61 & 264 & 18.77 \\
\hline
\end{tabular}

$* \mathrm{~S} / \mathrm{P}$ ratio value $=69.19 \%$

In total 68 out of 325 sera $(20.92 \%)$ were positive by VNT, whereas $61(18.77 \%)$ sera reacted positive by ELISA. No positive finding of antibodies against LSDV was detected by VNT in samples from the sera bank of the Scientific Veterinary Institute "Novi Sad", while by ELISA positive antibody finding was detected in one sample from the sera bank. In 200 sera samples from vaccinated cattle, positive finding was determined in 68 samples (34\%) by VNT and in 60 (30\%) samples by ELISA (Table 1).

Antibodies against LSDV became detectable 20 days after vaccination. Antibodies were detected in $6(30 \%)$ cows by VNT, and with antibody titer values in the range from 1:8 to 1:32 By ELISA, antibodies were detected in $2(10 \%)$ cows, with S/P values $50.73 \%$ and $63.80 \%$. The largest number of cows with positive antibody finding was detected 30 days after vaccination. Antibodies were found in $15(75 \%)$ cows by VNT with antibody titer values from 1:8 to 1:64, and in $13(65 \%)$ cows by ELISA, with S/P values from $29.97 \%$ to $170.47 \%$. Analyzing the results obtained by both tests, in the 
same vaccinated cows, it was found that the number of animals with antibodies against LSDV decreased nearly 50\% on days 45,60 and 75 after vaccination compared to day 30 after vaccination. On days 45 and 60 after vaccination, there was no significant reduction in antibody titer values, nor in the $\mathrm{S} / \mathrm{P}$ values, which were in the range from $1: 16$ to $1: 64$ and $141.14 \%$ to $146.35 \%$, respectively. On day 75 after vaccination, antibody titer values were slightly reduced, and were from 1:2 to 1:32, while S/P values were from $53.96 \%$ to $206.99 \%$. Positive finding of antibodies against LSDV by ELISA was found on days 90, 105 and 120 after vaccination in 8 cows (40\%). Testing of the same samples by VNT, antibodies against LSDV were found in 8 cows, except on day 105 after vaccination, when $9(45 \%)$ cows reacted positive. Antibody titer and S/P values were similar in the last three sampling intervals, and were in the range from 1:2 to $1: 128$ and from $42.39 \%$ to $270.19 \%$, respectively.

Antibodies against LSDV detected by comparative testing were also quantified. Based on the obtained results, it can be concluded that antibody titer values detected by VNT ranged from 1:2 to 1:64, and S/P ratio values determined by ELISA ranged from $29.97 \%$ to $270.19 \%$.

\section{Results of compatibility testing of VNT and ELISA for the detection of antibodies against LSDV}

Table 2 shows compatibility of the results obtained by VNT and ELISA using kappa test.

Table 2. Compatibility of VNT and ELISA for the detection of antibodies against LSDV

\begin{tabular}{lccccl}
\hline & & & MVNT & & Kappa index $=\mathbf{0 . 9 1 3}$ \\
\cline { 2 - 6 } cELISA & & + & - & $\Sigma$ & Standard error of kappa $=0.0285$ \\
& + & 60 & 1 & 61 & Overall proportion of agreement $=0.9723$ \\
& - & 8 & 256 & 264 & Kappa lower 95\% limit $=0.8571$ \\
& $\Sigma$ & 68 & 257 & 325 & Kappa upper 95\% limit $=0.9689$ \\
\hline
\end{tabular}

According to the obtained data shown, results of comparative testing did not match in only 9 out of 325 tested samples. Eight samples of vaccinated cows taken on days 20,30, 75 and 105 after vaccination were positive only by VNT, whereas one sample from the sera bank was positive only by ELISA. Firstly, on day 20 after vaccination, results of 4 samples did not match, with antibody titer values from 1:8 to 1:16 and $\mathrm{S} / \mathrm{P}$ values from $9.07 \%$ to $21.68 \%$. Secondly, on day 30 after vaccination, results of 2 samples did not match, with antibody titer values $1: 16$ and $\mathrm{S} / \mathrm{P}$ values $25.07 \%$ and $25.33 \%$. Thirdly, on days 75 and 105 after vaccination, results of 1 sample did not match, with antibody titer values $1: 2$ and $\mathrm{S} \backslash \mathrm{P}$ values $13.68 \%$ and $15.33 \%$. Finally, $\mathrm{S} / \mathrm{P}$ value of ELISA positive sample from the sera bank was $69.19 \%$, while no antibodies were detected by VNT in this sample. 
By VNT a positive finding was determined in 68 samples and a negative finding in 257 samples. On the other hand, by ELISA a positive finding was determined in 61 samples and a negative in 264 samples. Kappa index was 0.913 , which presents almost complete agreement of compared methods [8].

Specificity and sensitivity of VNT and ELISA for the detection of antibodies against LSDV by are shown in Table 3.

Table 3. Specificity and sensitivity of VNT and ELISA for the detection of antibodies against LSDV

\begin{tabular}{lcccc}
\hline & \multicolumn{2}{c}{ MVNT* } & \multicolumn{2}{c}{ cELISA** } \\
\cline { 2 - 5 } & Positive & Negative & Positive & Negative \\
\hline Positive & $68(\mathrm{TP})$ & $0(\mathrm{FN})$ & $60(\mathrm{TP})$ & $8(\mathrm{FN})$ \\
Negative & $0(\mathrm{FP})$ & $125(\mathrm{TN})$ & $1(\mathrm{FP})$ & $124(\mathrm{TN})$ \\
\hline
\end{tabular}

TP true positive, FN false negative, FP false positive, TN true negative.

Specificity: TN $/(\mathrm{TN}+\mathrm{FP}) * 125 /(125+0)=100 \% ; * * 124 /(124+1)=99,2 \%$

Sensitivity: TP $/(\mathrm{TP}+\mathrm{FN}) * 68 /(68+0)=100 \% ; * * 60 /(60+8)=88,24 \%$

Sera samples from the sera bank of the Scientific Veterinary Institute "Novi Sad" were used to calculate specificity of VNT and ELISA, because they could be considered as true negative samples on the presence of antibodies against LSDV, since historically at the time of collection of those samples, no LSD has ever been reported in Serbia. According to the obtained results, specificity of VNT and ELISA was 100\% and $99.2 \%$, respectively. However, determining of sensitivity, regardless of the obtained results, must be cautiously taken into consideration, as there were no positive reference samples on the presence of antibodies against LSDV included in testing.

\section{DISCUSSION}

According to the aim of this paper, the results of detection of antibodies against LSDV by VNT and ELISA methods in cattle are presented. Samples originated from the vaccinated cattle and cattle that were not in contact with LSDV. A virus neutralization test modified in relation to the VNT recommended by OIE [12] and commercial ELISA set kit were used for the detection of antibodies against LSDV. The modification of VNT in relation to the recommended VNT by OIE [12] refers to the virus used, cell culture and duration of the test. VNT was performed using homologous virus SERBIA/Bujanovac/2016 that originated from LSD clinically infected animal $[10,11]$, and was isolated on MDBK cell line. On the other hand, OIE recommends using Capripoxvirus for VNT [12]. Productive replication of isolated virus in MDBK cell line, with the development of a clearly visible cytopathogenic effect (Figure 2) allowed the test duration to be reduced from 9 days, which is recommended by OIE [12], to 3 days. Thus, VNT has an advantage in relation to the recommended 
virus neutralization test by OIE and a great potential in the serological diagnostics of LSD. The obtained results of 100\% regarding specificity of VNT are in accordance with statements by other authors [14,21]. Virus neutralization test is considered to be the most specific serological method, but it is not sensitive enough to detect antibodies in each animal that have been in contact with the virus $[9,12,13]$.

Due to the local spread of the virus from cell to cell, effector cells of cell mediated immune response, such as natural killer cells or cytotoxic $T$ lymphocytes are necessary to identify and eliminate infected cells to prevent virus replication and spreading [16]. In studies considering Orthopoxviruses it was concluded that joint action of humoral and cellular immune responses was necessary for the clearance of the infection, whereas for protection against reinfection sole action of humoral immune response was enough [3]. Due to the lack of commercial diagnostic assays based on the cellular immune response or assays for quality control of vaccine production [3], and the fact that the role of of antibodies has been demonstrated in several studies, where animals did not have detectable level of antibodies in their sera, but were resistant to challenge $[14,17]$, it is very important to improve diagnostics of LSD by available commercial assays like VNT and ELISA.

Absolute specificity of virus neutralization test was proven by Bowden et al [14]. They tested two experimentally infected calves that developed neutralizing antibodies 21 day after infection, while ELISA detected the presence of antibodies only in one calf. Moreover, antibodies were detectable by ELISA from 21 to 35 days after infection, while by VNT from 28 to 42 days after infection. Babiuk et al [21] also compared the performances of VNT and ELISA and determined that sensitivity of both VNT and ELISA was $96 \%$, while specificity of VNT and ELISA was $100 \%$ and $95 \%$, respectively. Furthermore, detection of antibodies against LSDV by indirect ELISA (iELISA) was performed by Walid et al. [22] in 25 clinically infected, 9 fevered and 21 in-contact cows. Antibodies against LSDV were detected by iELISA in $56 \%$ of clinically infected cows and in one $(11,11 \%)$ fevered cow. None of in-contact cows had antibodies against LSDV. In the study conducted by Tilahun et al. [23] the first presence of antibodies in annually vaccinated cattle was determined 7 days after vaccination. In the majority of cows, the seroconversion was determined 21 days after vaccination, while the highest neutralizing antibody level was detected 35 days after vaccination. In addition to that, antibodies at high level were detectable by VNT up to 63 days following regular annual vaccination. No antibodies were detected in the majority of annually vaccinated cattle before the start of the study, which shows that duration of detectable humoral immune response could be less than a year.

Looking at the results of antibody detection in vaccinated cows in this paper, it can be concluded that our results are similar to the results obtained by other authors $[18,23]$, that the highest seroconversion is detected 30 days after vaccination, and that the first presence of antibodies can be detected 20 days after vaccination. 
The results obtained in this study indicate the need for further testing of the sensitivity of VNT, regardless of the fact that effectors of cellular immune response have the dominant role in the development of immune reactivity against LSD. It is also necessary to continue comparative testing of infected cattle sera by VNT and ELISA.

\section{CONCLUSION}

Virus neutralization test and commercial ELISA manufactured by „IDvet“ can be used for the detection of antibodies against LSDV. The compatibility of the results obtained by both tests was exceptionally high, since the calculated kappa index was 0.913. Specificity of VNT and commercial ELISA was $100 \%$ and $99.2 \%$, respectively. VNT allows the test to be performed within 3 days using isolated LSDV from clinically infected animal, and not 9 days using Capripoxvirus, like OIE recommends.

In vaccinated cattle the first presence of antibodies against LSDV was detected 20 days after vaccination by VNT and commercial ELISA. The highest seroconversion in vaccinated cattle was determined 30 days after vaccination. Antibodies against LSDV were detected from the vaccination day until the fourth month after vaccination by VNT and commercial ELISA in 34\% and 30\% of vaccinated cattle, respectively.

\section{Acknowledgements}

This study was supported by the Ministry of Education, Science and Technological Development of the Republic of Serbia, Project number TR 31084 and Project number TR31071.

\section{Authors' contributions:}

SM conducted tests and writing the first draft of the paper. LS, PT and PV created the experimental design. PV and GV performed sampling. LD and LG performed the analysis of the results. PT participated in the isolation of the virus and reading of the results. LS participated in the isolation of the virus, reading of the results and writing of the paper. All authors have approved the final version of the manuscript.

\section{Declaration of conflicting interests:}

The author(s) declared no potential conflicts of interest with respect to the research, authorship, and/or publication of this article. 


\section{REFERENCES}

1. Hawsar YA, Heshu SR, Hiewa OD and Hemn HO: Lumpy Skin Disease. Reproductive Immunol Open Acc 2016, 1, 4:25.

2. Abutarbush MS.: Hematological and serum biochemical findings in clinical cases of cattle naturally infected with lumpy skin disease. J Infect Dev Ctries 2015, 9 (3):283-288.

3. Tuppurainen ESM, Venter EH, Shisler JL, Gari G, Mekonnen GA, Juleff N, Lyons NA, De Clercq K, Upton C, Bowden TR, Babiuk. S, Babiuk LA: Review: Capripoxvirus Diseases: Current Status and Opportunities for Control. Transbound Emerg Dis 2017, 64(3), 729745 .

4. Carn VM, Kitching RP: The clinical response of cattle experimentally infected with lumpy skin disease (Neethling) virus. Arch virol 1995, 140, 3:503-513.

5. International Committee on Taxonomy of Viruses, Virus Taxonomy: 2015 Release, EC 47, London, UK, July 2015.

6. Babiuk S, Bowden TR, Parkyn G, Dalman B, Hoa DM, Long NT, Vu PP, Bieu DX, Copps J, Boyle DB: Yemen and Vietnam capripoxviruses demonstrate a distinct host preference for goats compared with sheep. J Gen Virol 2009, 90:105-114.

7. Davies FG: Lumpy skin disease, an African Capripoxviruses Disease of Cattle. Br Vet J 1991;147:489-502.

8. Tulman ER, Alfonso CL, Lu Z, Zsak L, Sur J-H, Sandybaev NT, Kerembekova UZ, Zaitsev VL, Kutish GF, Rock DL: The genomes of sheeppox and goatpox viruses. J Virol 2002, 76(12): 6054-6061.

9. EFSA (European Food Safety Authority) Scientific report on lumpy skin disease: I. Data collection and analysis. EFSA Journal 2017, 15(4):4773, 54 pp.

10. Vidanović D, Šekler M, Petrović T, Debeljak Z, Vasković N, Matović K, Hoffmann B: Realtime PCR assays for the specific detection of field Balkan strains of Lumpy skin disease virus. Acta Vet-Beograd 2016, 66 (4):444-454.

11. Toplak I, Petrović T, Vidanović D, Lazić S, Šekler M, Manic M, Petrović M, Kuhra U: Complete genome sequence of Lumpy skin disease virus isolate SERBIA/Bujanovac/2016, detected during an outbreak in the Balkan area. Genome Announc (American Society for Microbiology) 2017, 5, 35:1-2.

12. OIE Terrestrial Manual: Lumpy skin disease. 2016, Chapter 2.4.13.

13. EFSA (European Food Safety Authority) Scientific Opinion on lumpy skin disease: EFSA Panel on Animal Health and Welfare. EFSA Journal 2015, 13(1):3986, 67 pp.

14. Bowden TR, Coupar BE, Babiuk SL, White JR, Boyd V, Duch CJ, Shiell BJ, Ueda N, Parkyn GR, Copps JS, Boyle DB: Detection of antibodies specific for sheeppox and goatpox viruses using recombinant capripoxvirus antigens in an indirect enzyme-linked immunosorbent assay. J Virol Methods. 2009,161(1):19-29.

15. Gari G, Biteau-Coroller F, LeGoff C, Caufour P, Roger F: Evaluation of indirect fluorescent antibody test (IFAT) for the diagnosis and screening of lumpy skin disease using Bayesian method. Vet Microbiol 2008, 129:269-280.

16. Seet BT, Johnston JB, Brunetti CR, Barrett JW, Everett H, Cameron C, Sypula J, Nazarian SH, Lucas A, McFadden G: Poxviruses and immune evasion. Anu Rev Immunol 2003, 21:377-423.

17. Kitching RP: Passive protection of sheep against capripoxvirus. Res Vet Sci 1986, 41:247250 . 
18. Hunter P, Wallace D: Lumpy skin disease in southern Africa: A review of the disease and aspects of control. J S Afr Vet Assoc 2001, 72 (2), 68-71.

19. Hedger RS, Hamblin C: Neutralising antibodies to lumpy skin disease virus in African wildlife. Comp. Immun. Microbiol Infect Dis 1983, 6, 3, 209-213.

20. Babiuk S, Bowden TR, Parkyn G, Dalman B, Manning L, Neufeld J, Embury-Hyatt C, Copps J, Boyle DB: Quantification of Lumpy Skin Disease Virus Following Experimental Infection in Cattle. Transboun Emerg Dis 2008,55:299-307.

21. Babiuk S, Wallace DB, Smith SJ, Bowden TR, Dalman B, Parkyn G, Copps J and Boyle DB: Detection of Antibodies Against Capripoxviruses using an inactivated Sheeppox virus ELISA. Transbound Emerg Dis 2009, 56:132-141.

22. Walid SA, Adel KI, Khaled M, Khaled MF, Mervet IAM: Evaluation of different diagnostic methods for diagnosis of Lumpy skin disease in cows. Trop Anim Health Prod 2010, 42 (4):777-783.

23. Tilahun Z, Berecha B, Simenew K, Reta D: Towards effective vaccine production: A controlled field trial on the immunological response of three lumpy skin disease vaccine strains in dairy farms. Acad J Anim Dis 2014, 3(3):17-26.

24. Thrusfield M: Veterinary epidemiology, Third edition, Veterinary Clinical Studies Royal (Dick) School of Veterinary Studies University of Edinburgh, Blackwell Science Ltd, Press: 2007, 305-329.

\title{
DETEKCIJA ANTITELA PROTIV VIRUSA BOLESTI KVRGAVE KOŽE METODAMA VIRUS NEUTRALIZACIJE I ELISA
}

\author{
SAMOJLOVIĆ Milena, POLAČEK Vladimir, GURJANOV Vladimir, \\ LUPULOVIĆ Diana, LAZIĆ Gospava, PETROVIĆ Tamaš, LAZIĆ Sava
}

Infekcija goveda virusom bolesti kvrgave kože (lumpy skin disease virus -LSDV) je veoma važna sa aspekta govedarske proizvodnje. Iako može da izazove velike ekonomske gubitke, dostupni serološki testovi još uvek nisu dovoljno efikasni i pouzdani. Radi unapređenja serološke dijagnostike bolesti kvrgave kože (LSD) virus neutralizacioni test (VNT) je izvođen upotrebom kulture ćelija Madin-Darby bovine kidney (MDBK) i LSDV poreklom od klinički obolelog govečeta u trajanju od 3 dana.

Uporedno je ispitano 325 uzoraka krvnih seruma koji su poticali od 125 krava pre pojave LSD u Republici Srbiji, a 200 uzoraka je bilo poreklom od vakcinisanih krava. Krvni serumi vakcinisanih krava su prikupljani od dana vakcinacije, pa do 4 meseca posle vakcinacije. Uzorkovanje je vršeno u 7 vremenskih intervala nakon vakcinacije kod krava poreklom sa jedne farme, dok je u 3 vremenska intervala vršeno uzorkovanje kod 20 različitih krava u svakom terminu uzorkovanja.

Od ukupno 200 uzoraka poreklom od vakcinisanih krava, antitela protiv virusa LSD su utvrđena kod 68 (34\%) uzoraka VNT, a ELISA kod 60 (30\%) uzoraka. U uzorcima 
pre pojave LSD u Republici Srbiji, VNT nije utvrđen ni jedan uzorak sa pozitivnim nalazom, a sa kELISA jedan uzorak je bio sa pozitivnim nalazom antitela protiv virusa LSD. Antitela protiv LSDV kod vakcinisanih krava su utvrđena, sa oba testa, od 20-og dana posle vakcinacije, a najviše životinja sa antitelima protiv LSDV su utvrđena 30-og dana posle vakcinacije.

Upoređivanjem rezultata ispitivanja, dobijenih VNT i ELISA, utvrđeno je da kappa indeks iznosi 0,913. Takođe, utvrđeno je da specifičnost VNT iznosi 100\%, a ELISA $99,2 \%$. VNT u odnosu na preporučeni virus neutralizacioni test od strane OIE je jednostavniji za izvođenje i može da unapredi serološku dijagnostiku LSD uz dodatna ispitivanja osetljivosti. 